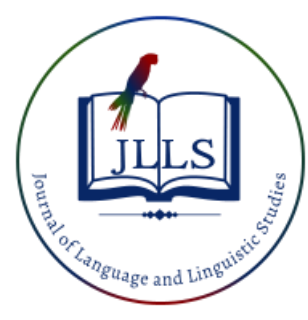

Available online at www.jlls.org

JOURNAL OF LANGUAGE

AND LINGUISTIC STUDIES

ISSN: $1305-578 \mathrm{X}$

Journal of Language and Linguistic Studies, 17(2), 736-740; 2021

\title{
Analysis of feminist concepts in Nalini Jameela's the autobiography of a sex
}

\author{
worker
}

\author{
Lois Sara Joice I a 1 iD, B. Sivakami b iD \\ ${ }^{a, b}$ Vellore Institute of Technology, Chennai, India
}

\section{APA Citation:}

Joice, I., \& Sivakami, B. (2021). Analysis of feminist concepts in Nalini Jameela's the autobiography of a sex worker, 17(2), 736-740. Doi: $10.52462 /$ jlls. 51

Submission Date: 02/01/2021

Acceptance Date: $02 / 03 / 2021$

\begin{abstract}
Women make significant decisions during desperate situations and even choose to do odd jobs to care for their families. Particularly Indian women put an end to their true identity to care for their children. India is known for its varied language and cultural practices. Different languages are spoken across the country, their culture differs from state to state, and their customs play a vital role with regard to religion. They worship different Gods, yet they remain united which is why it is called the country of 'Unity in Diversity. Despite the differences, all Indian women have certain common featured in them. Chastity is blended in the blood of every Indian woman. They tend to protect it throughout their lifetime. But unfortunately, some women are pushed to the position where they have to sell their chastity to provide for the family's sake. Even though the husband or the father is regarded as the primary breadwinner, today in so many Indian families women take up the family responsibility. They even choose to take up odd jobs such as surrogates and sex workers. This paper deals with the bottled-up emotions of one such woman and the consequences of the choice she made to take care of her family. The paper also argues the interconnection between the feminist concepts that are taken up for analysis.
\end{abstract}

Keywords: Autobiography; Crisis; Family; Finance; Hard work; Poverty; Profession

\section{Introduction}

'I am a wife, mother, author, social activist, and sex worker. I play many roles in my day-to-day life like others. I want to be respected in all my avatars' (Zee News, 2009).

Feminism in India was quite different during the medieval ages when compared to feminisms all over the world. The marginalized are neglected in India, like the black women in the United States. Women who come under this category are Dalit, sex workers, lesbians, trans-female, tribal, and women of the lower class. These women were never given a position in feminism; instead, it spoke for the elite group who were already enjoying partial freedom. All the world knew was only about the elite group and not the commoners. The unheard cries of the marginalized were brought out only through folklore tradition and oral tradition. However, until now women are suffering patriarchy and unable to voice for themselves. Feminism in postmodern India has undergone so many alterations and

\footnotetext{
${ }^{1}$ Corresponding author.

E-mail address: joylois1@gmail.com
} 
is voicing out for almost all the category which includes sex workers and lesbians. There is a wrong notion about the word "Sex", but people have failed to look into the actual meaning of it. The word "Sex" refers to the innate and biological aspect' (m Önem, 2016). Writers such as Mahasweta, Gayatri Spivak, Sharmila Rege are some of the great feminist scholars who laid the path to modern feminism in India. At first, feminism dealt with rights to vote, social rights, equality, discrimination issues, and identity crisis. But now there is a lot more than that the feminists are fighting for. While discussing women's rights with regard to the select work the Choices women make and the Care that they give and receive in the family and in society stand significant. The paper focus is on these two feminist concepts Choice and Care that are highlighted in The Autobiography of a Sex Worker written by the social activist, author, and sex worker Nalini Jameela.

\subsection{Background}

Initially, the book was written in Malayalam and was later translated to English by J. Devika. More than 13,000 copies were sold out in 100 days and the book became very popular. Jameela had said in one of her interviews that sex workers are viewed as inferior figures in society, so the book is written for them to get rid of the stigma that is floating around. This conveys the fact that she had much concern for her family and her profession. Jameela gained dignity and fame with the choice she made. It made her a public speaker, a social activist, and an author; however, she was addressed as a sex worker in literary festivals. The existing stereotype across the globe is that women are forced to do sex work. Here, the protagonist chose to do sex work to take care of her family. Existing researches have discussed either choice or care and the concepts were never brought together. The identified research gap is to observe the interconnection between choice and care. While focusing on the interconnection between the feminist concepts of choice and care, this paper will bring out the honest description of Jameela in multiple avatars.

\subsection{Research question}

How are choice and care interconnected in the select work?

\section{Theory}

\subsection{Choice}

Aristotle proposed the word Choice for the original translation of the Greek word 'prohairesis'. However the other proposed translations include 'decision', 'commitment', 'purpose', 'preferential choice, and established preference'; 'Choice' is the preferred translation overall (Hauptmann, 1996, p. 37, 38). According to Edward S. Shapiro and Christina L. Cole, 'there does not appear to be an accepted definition of "choice" or "choice-making" in literature. Brigham (1976) defines choice as "the opportunity to make an uncoerced selection from external influence'. He also gives a descriptive definition of choice as 'The act of an individual's selection of a preferred alternative from among several familiar options. To meet this definition, (1) the person must be able to reliably express personal preferences, and (2) the options must be familiar to the person (Shapiro \& Cole, 1994, p. 132). According to Angela Campbell, Choice is a 'link to agency and is thus viewed as a selection made in the face of multiple possibilities. The choice may or may not include consent to the circumstances surrounding a decision (Campbell, 2016, p. 11). William Glasser states that 'we choose everything we do, including the misery we feel. Others cannot take the responsibility for their state of mind (Glasser, 1999, p. 3). Mary Caputi captures choice feminism as 'a version of things that focuses on the gender of the person making the choice rather than the nature of what is being decided' (Caputi, 
2015, p. 141). It simply means that any choice made by a woman gives her a brand called feminist, despite the profession she is into. Be it a nurse or a sex worker, that doesn't matter. Janice G. Raymond argues that 'the sex work ideologues use a simplified definition of choice as freedom from coercion.' But their ability to choose depends on 'emotional and physical health, education, and financial standing'. Viewing prostitution from a conservative standpoint, women and girls are blamed for choosing prostitution, but from a liberal point of view it is romanticized as 'sex work' and 'whatever happens to her in the prostitution is normal because it is her choice' (Raymond, 2013, p. 20). The existing stereotype is that women are coerced to make certain decisions. But concerning the select work, the protagonist has made an uncoerced selection of profession to care for her family. It challenges the prostitute stereotype and strips the reality.

\subsection{Care}

Fisher and Tronto gave a broad definition of care as:

'a species activity that includes everything that we do to maintain, continue and repair our 'world' so that we can live in it as well as possible. That world includes our bodies, ourselves, and our environment, all of which we seek to interweave in a complex, life-sustaining web' (Tronto, 2013, p. 19).

Francesca Cancian stated a narrow definition of Care following the pioneering British sociologist Janet Finch and Dulcie Groves. According to him, care is a state of 'affection and responsibility that provides the 'individual's personal needs and their well-being' (Tronto, 2013, p. 19, 20). Tronto conceptualizes Care in four ways: Caring about is the first stage and it is the primary acknowledgment of the 'care needed.' There is a relationship concerning 'what we care about and the kind of individual we are says Tronto. Taking Care of is the second stage and it exhibits the notions of 'agency and responsibility. Tronto claims that the individual is obliged to suffice the need required and determines 'how to respond to it. The third stage caregiving denotes that the process involves 'physical work' for all those who are in need. Tronto states that slaves, servants, and women are the predominant caregivers. The last and final stage is care-receiving where the 'care needs are met. This stage is considered to be the least of all because of the state of 'dependency' that is involved here. Since the care needs are met, the one who is in much need is the most dependent (Hughes, 2002, p. 108-110). Regarding the select work, the protagonist is viewed as both caregiver and care receiver. The systematic analysis of the work has identified that the concept of care is explicit throughout. The author intends to take care of her family because of which she chose to do odd jobs.

\section{Analysis \& Discussion}

To analyze choice and care from a feminist standpoint, Nalini Jameela's The Autobiography of a Sex Worker is an excellent example. Here Jameela exposes the certainty in a sex worker's day-to-day life. At the age of 9, she had to discontinue schooling because of her aunt; she said: 'this girl has finished the third class, she needn't go anymore' (Jamila, 2015, p. 16). Denial of education was a major drawback in her life. Even at a very young age, choice played a significant role in her life. Due to extreme poverty in the family, she took up difficult jobs like working in the clay mine and tile factory. Tronto's caregiving concept states that slaves, servants, and women are the predominant caregivers (Hughes, 2002, p. 109). He also claims that the involvement of physical work is a major key factor in caregiving. Jameela chose to do tough physical jobs to take care of her mother. Considering Hughes's statement, Jameela being a young girl, served as the primary caregiver for her family. Provided two male members in the family, it was Jameela who toiled day and night to take care of the family. During these difficult times 'thought enabled her to interpret the events occurring 
around and to find a way to survive' (Taşdan, 2018). Unlike other girls, she did not stay at home after stopped from schooling; instead, she chose to work. When her father threw her away from the family, she had to marry for the sake of protection and shelter. When the husband died leaving behind two children to take care of, she started sex work: 'I started sex work after my husband's death when my mother-in-law began demanding a really large sum from me daily to support my children...My mother-in-law asked for five rupees every day' (Jameela, 2015, p. 32). In India, marriage is not a choice for many women, but here the protagonist chose to get married. However, the sudden demise of her husband made her choose sex work. So firstly, she chose to get married to take care of herself; secondly, she chose to do sex work to take care of her children. As Glasser stated, 'we choose everything we do, including the misery we feel' (Glasser, 1999, p. 3) though it was hard during the initial days, Jameela chose to do sex work to support her children and to take care of them. Here, Tronto expresses that taking care of someone in need is taking up the responsibility. Jameela took up the responsibility as a daughter as well as a mother. Not only care was given, but she also received care from her relatives and doctors while hospitalized. Her 'care needs were met' (Hughes, 2002, p. 110) during hopeless situations. Even though the choice made her life miserable, needs were met. A clear picture of the intersection of choice and care is explicit through the select work.

After so many hardships, she joined Jwalamukhi, the organization that worked for the rights of the sex workers. This decision made her successful, gave her fame, dignity with which she was able to take care of herself and her daughter. At this juncture, choice and care are vividly visible. The choice she made gave her respect as a daughter who took care of her mother by tirelessly working in the factory, a mother who chose to do sex work to take care of her children, a sex worker who took care of the physical needs of men, as a social activist who stood up for her co-sex workers and as an author who represented the harsh realities.

\section{Conclusions}

During the initial days, the protagonist did not have a choice yet there were a lot of troublesome days because of the choice she made. The consequences of the choice helped her to care for herself and her family. Tronto's care conceptualization is intensified in this work. Care and choice are interconnected in such a way that most of the time they go hand-in-hand. The protagonist had made certain important decisions in her life which helped her to take care of her family. After a detailed analysis, the observed research finding is that there is an interconnection between the feminist concepts of choice and care. Concerning the select work, initially, the choice that the protagonist made did not provide her with a dignified identity in society. But in the latter part, it is observed that the same choice not only helped her to take care of her family but also made her successful. To conclude, despite the fact that women are being branded as feminists for making their choices, society has to acknowledge the fact that they do have a choice. If they are left to make their own decisions they will become a catalyst in building the nation.

\section{References}

Campbell, A. (2016). Sister wives, surrogates and sex workers: Outlaws by choice? New York, USA: $\begin{array}{lllll}\text { Routledge. } & \text { Retrieved } & \text { November } & \text { 2020, from }\end{array}$ www.google.co.in/books/edition/Sister_Wives_Surrogates_and_Sex_Workers/zabeCwAAQBAJ?h $1=\mathrm{en} \& \mathrm{gbpv}=1$.

Caputi, M. (2015). Feminism and Power: The need for critical theory. Plymouth, United Kingdom: Lexington Books. Retrieved November 24, 2020, from 
https://www.google.co.in/books/edition/Feminism_and_Power/bbNNbCsrk8cC?hl=en\&gbpv=1\&d $\mathrm{q}=$ Feminism+and+power:+the+need+for+critical+theory\&printsec $=$ frontcover

Glasser, W. (1999). Choice theory: A new psychology of personal freedom. New York, United States: Harper Perennial. Retrieved November 23, 2020, from www.google.co.in/books/edition/Choice_Theory/fiDW8_QzNTcC?hl=en\&gbpv=1\&dq=choice+th eory+william+glasser\&printsec=frontcover.

Hauptmann, E. (1996). Putting choice before democracy: A critique of rational choice theory. Albany, USA: State University of New York Press. Retrieved December 2, 2020, from www.google.co.in/books/edition/Putting_Choice_Before_Democracy/YIAhjiZ_7WMC?hl=en\&gb $\mathrm{pv}=1 \& \mathrm{dq}=$ definition $+\mathrm{of}+$ choice $\& \mathrm{pg}=\mathrm{PA} 37 \&$ printsec $=$ frontcover.

Hughes, C. (2002). Key concepts in feminist theory and research. London, United Kingdom: SAGE Publ. Retrieved December 15, 2020, from https://www.google.co.in/books/edition/Key_Concepts_in_Feminist_Theory_and_Rese/wpB9VklJ $0 \mathrm{p} 8 \mathrm{C} ? \mathrm{hl}=\mathrm{en} \& \mathrm{gbpv}=1 \& \mathrm{dq}=\mathrm{Key}+\mathrm{concepts}+\mathrm{in}+$ feminist + theory+and+research $\&$ printsec $=$ frontcover

Jamīla, N. (2015). The autobiography of a sex worker (1210732701 902284693 J. Devika, Trans.). Chennai, Tamil Nadu: Westland Books.

M Önem, E. E. (2016). A study on gender differences in the length of requests in Turkish. Journal of Language and Linguistic Studies, 12(2), 13-21.

Raymond, J. G. (2013). Not a choice, not a job: Exposing the myths about prostitution and the global sex trade. Washington, D. C., USA: Potomac Books. Retrieved December 2, 2020, from https://www.google.co.in/books/edition/Not_a_Choice_Not_a_Job/dyd8AwAAQBAJ?hl=en\&gbp $\mathrm{v}=1 \& \mathrm{dq}=$ not $+\mathrm{a}+$ choice + not $+\mathrm{a}+$ job $\&$ printsec $=$ frontcover.

Shapiro, E. S., \& Cole, C. L. (1994). Google Books. New York, USA: The Guilford Press. Retrieved December 2, 2020, from https://books.google.rw/books?id=Aumfst$\mathrm{ZK} 84 \mathrm{C} \&$ printsec $=$ copyright $\& \mathrm{hl}=\mathrm{en} \# \mathrm{v}=$ onepage $\& \mathrm{q} \& \mathrm{f}=$ true

Taşdan, T. E. (2018). Intertextuality in Albert Camus's philosophy: "Let us imagine Sisyphus happy". Journal of Language and Linguistic Studies, 14(2), 173-182.

Tronto, J. C. (2013). Caring democracy: Markets, equality, and justice. New York, USA: New York University Press. Retrieved December 17, 2020, from https://www.google.co.in/books/edition/Caring_Democracy/8HL0IiVr2-

$\mathrm{sC} ? \mathrm{hl}=\mathrm{en} \& \mathrm{gbpv}=1 \& \mathrm{dq}=$ Caring+democracy: + markets, + equality,+ and + justice $\&$ printsec $=$ frontcover

'I m Introduced as Sex Worker'. (2009, December 12). Retrieved December 30, 2020, from https://zeenews.india.com/entertainment/bookworm/bookworm-s-trail/-i-m-introduced-as-sexworker_535.htm

\section{AUTHOR BIODATA}

Lois Sara Joice I is a Research Scholar in the field of English language and Literature at Vellore Institute of Technology, Chennai Campus. Her research area of Interest is Literature.

B. Sivakami working as an Assistant Professor in the department of English Language and Literature at Vellore Institute of Technology Chennai Campus. Her research area of interest is Literature and ELT. 